\title{
Non-Motorized Public Transport and Tourism - The Case of Pedicab Drivers of Catbalogan, Samar, Philippines
}

Irene EA*, Laurilla FT and Bajado JC

Samar State University, College of Education, Catbalogan City, Philippines

*Corresponding author: Elmer A. Irene, Samar State University, College of Education, Catbalogan City, Philippines, Tel: 639175621866; Email: elmer_irene@yahoo.com

Rec date: Jul 15, 2015, Acc date: Aug 20, 2015, Pub date: Aug 27, 2015

Copyright: () 2015 Irene EA, et al. This is an open-access article distributed under the terms of the Creative Commons Attribution License, which permits unrestricted use, distribution, and reproduction in any medium, provided the original author and source are credited.

\begin{abstract}
Non-motorized public transport such as Pedicab or tricycle rickshaw earns the advantage of a fast way to earn money but in the context of the marginalized sector, it is professions they know for a living and majority of these Pedicab drivers never escape the bondage of poverty. The authors surveyed the status of Pedicab operations in Catbalogan City and its role to the tourism industry. It employed both quantitative and qualitative methods, capitalizing from results of the quantitative analysis and key informant interviews. Results show that there was a decreasing trend in the number of Pedicab units but found no significant differences in the number during the threeyear period (2011-2013). The data also shows most of Pedicab drivers came from outskirts of the city, mostly elementary graduate but others have finished two to four-year college courses, married and in their early adulthood. Majority spent five to eight hours of driving a day and has spent more than five years in pedicab driving, but their economic condition barely improved. Tourism is generally viewed as the key in improving their income but on how to achieve it is uncertain. Pedicab operators are found to be lackluster in their efforts in preparing for tourism such as restructuring their Pedicab units to make it tourist-friendly and attractive. A policy must be institutionalized in order to regulate and monitor the number and operation of the Pedicab.
\end{abstract}

Keywords: Pedicab operations; Socio-economic; Local tourism; Catbalogan; Samar

\section{Introduction}

Tourism is one of the largest industries that could boost development in the countryside. It is a major alternative source of income of the local sector wherein huge influx of visitors are buying local commodities and creating livelihood to the locals. Samar boasts of its attractive tourist spots that not only attract local but international tourists as well. The challenge is to develop the site and provide facilities such as hotels and airports. The regional director of Department of Tourism in region 8 was adamant when she stressed that developing tourism is not an overnight activity. However, developing a place for tourism is not the issue, one should make the community and the different stakeholders are ready for tourism. There should be an emphasis on a community-based empowerment regarding tourism by concerned local government (Sowman) [1] and a national policy strategy should back up the efforts in the local level (Connell Page and Bentley) [2] to gradually profit from the benefits that tourism can bring to the people in the community.

The front liners in the tourism industry are the tourist workers such as the local officials, tour guides, salespersons and local tour agencies staff. But there is one under-research tourism workers who do not get much attention but significantly contribute to the industry, that is, the petty pedicab drivers [3]. These pedicab drivers enthusiastically attend to tourists because of the extra fees from the tourists for their pedicab service. Pedicab industry is now a booming industry that is not only operational in developing countries but in industrialized countries as well. There are now pedicab operators in New York, Macau and other tourist-packed places [4] These tourist workers play a significant role in the tourism industry because they can be easily accessed, they maneuver the narrow streets and tourists enjoy the nature-friendly, open-air ride and sightseeing of the place through Pedicab travel. If this industry can be enhanced and the different sectors would corroborate, then Samar Tourism Industry can flourish.

Pedicab driving is a source of employment in Catbalogan city. It is the source of employment of the poor because there are fewer job opportunities present in the area especially for undergraduate employees. However, looking at the trends of number of pedicab drivers, it indicates that this is the fastest means of income and many locals grab this opportunity to earn money. This is one big opportunity for countryside development through this industry if the pedicab operators and drivers can attract tourists by proper behavior and professionalism.

On the other side, unlike the pedicab drivers in New York and other US cities (Conway and Khallouki) [5] there is an inhibition among these unsung tourist workers in the countryside, that is, their behavior and physical get up can negatively impress the tourists. Rogues are just many of pedicab drivers that in most of these instances, these pedicab drivers display uncomfortable stance to the fear of the tourist that a hidden intention is looming on the side. Further, they do not manifest professional manners that tourists will find it a form of inhospitality and can adversely contribute to tourism. However, it is not a hopeless case because pedicab operators can help enhance the tourism industry in Samar if only they are properly guided and policies are in effect [6]. But involving these pedicab drivers and operators in research is challenged with contrast and non-cooperation because many of them being wary of unnecessary exposures and of outsiders' nosiness. Thus, there is a rarity of literature available about pedicab drivers in Catbalogan City. 
Catbalogan City is a first class municipality before it was converted recently into a city. This Western Samar capital is strategically located for commercial, trading, educational, political and financial activities. It has a population of 94,317 (2010 Census) and a total land area of 274.22 square kilometers. Despite the financial opportunities in the city, the face of poverty is still prevalent in the area. Poverty incidence is high and has not changed much from 37.4 in 2009 to 36.0 in 2012. The island of Samar has the ten poorest municipalities of the Philippines and the region is one with a high incidence of poverty. Region VIII's worst poverty incidence of families rose from 35.3 percent in 2003 to 40.7 percent in 2006 (National Economic Development Authority, 2010).

The research project posits that if tourism industry can be enhanced, new jobs will be created and local industries will profit as well [7-9]. The job of the poor can be transformed into a tool boosting the tourism industry. Moreover, the study can be one of the means to fill the existing research gap on pedicab operations in the Philippines. Factors identified in the study can be used as baseline in reviewing local policies or assessing the need for providing one at the national level and empowering silent tourist workers in the countryside.

In general, this study aimed to assess the pedicab operations and their role in the tourism industry in Catbalogan City. Specifically, it sought to determine the profile of the Pedicab driver and operators in the City, their needs, problems and ailments encountered as well as their recreations, benefits received and aspirations in life. Moreover, it sought to assess their violations and complaints against their Pedicab operation and how tourism can boost the income of these Pedicab drivers.

\section{Materials and Methods}

The researchers used quantitative and qualitative research methodologies to assess the status of the pedicab operations in Catbalogan City. Specifically, it employed an exploratory research design in which respondents were pedicab drivers/operators of Catbalogan City who were asked using an interview schedule. A researcher-made interview schedule comprising of sub-sections for the themes revolving around: Profile; Problems, needs and ailments; Recreation, benefits and aspirations of Pedicab drivers; Complaints and violations committed; and Perceived role of Tourism to increase the income of Pedicab drivers. The data was analyzed through multiple data analysis. Simple frequency count and percentage analysis were used to present the descriptive data. Further, documentary analysis and focus group discussions were also employed to validate the data gathered through interview schedules.

Research locale is the city of Catbalogan, home to about 94,000 residents spread out in its 57 barangays (village) of which 22 is located in the city proper while others are rural, upland and island barangays. Since the concentration of pedicab operations is in the city proper, only pedicab drivers and operators operating in the city proper were involved in the study.

\section{Results and Discussion}

There were 220 pedicab drivers who were interviewed in the study but all those registered pedicab drivers in the city hall from the period
2011-2013 were included in the database. The respondents were randomly selected through convenient sampling because not all Pedicab drivers were registered in the city hall. Fifty operators (employers) were also included in the database and were determined through the names revealed by the drivers. The survey was conducted during the period from June 2014 to October 2014.

Documents available from the city hall revealed that there were about 1689 registered pedicab drivers and 357 operators in 2011, but this number decreased to 793 and 270 for drivers and operators respectively in 2013. The following graph shows the trend of registered Pedicab drivers and operators in Catbalogan city from 2011 to 2013.

\section{Registration of Pedicab Drivers and Operators from 2011-2013}

It can be gleaned from the graph that there is a regressing trend of the number of Pedicab drivers with about $30 \%$ decrease of their number every year from 2011 to 2013 while the number of operators pegged an almost constant figure. One of the reasons that surfaced was that since there is a growing competition between the motorized cab drivers, the pedicab drivers find it necessary to shift from pedal to a motor which is more convenient and less hard work. Some operators also acquired motorized cabs and maintain their franchise (Figure 1).

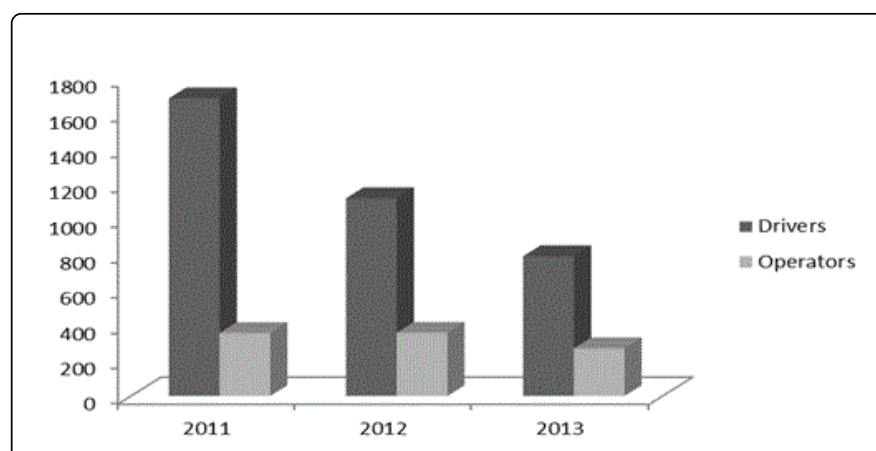

Figure 1: Trend of Registration of Pedicab drivers and operators from 2011-2013.

In terms of the number of pedicab units owned by pedicab operators, it can be seen in Figure 2 that there is not much variation in terms of the number in the three-year period. There are operators who maintain their franchise and lost one or two pedicab units only. During FGD, these operators revealed that they sold their old units and did not buy new ones. Instead, some operators have shifted to motorized cabs. Evidently, there are 11 operators who lost all their units from as low as three to 30 in 2011 to none or almost zero in 2013. Asking where their Pedicab units went, some informants told that there were instances when their relatives took over the management and change the registration to the new operators. Remarkably, three operators increase their number of units to almost 200 percent from their previous number of pedicab units (Table 1). 
Citation: Irene EA, Laurilla FT, Bajado JC (2015) Non-Motorized Public Transport and Tourism - The Case of Pedicab Drivers of Catbalogan, Samar, Philippines. J Socialomics 4: 118. doi: 10.4172/2167-0358.1000118

Page 3 of 7

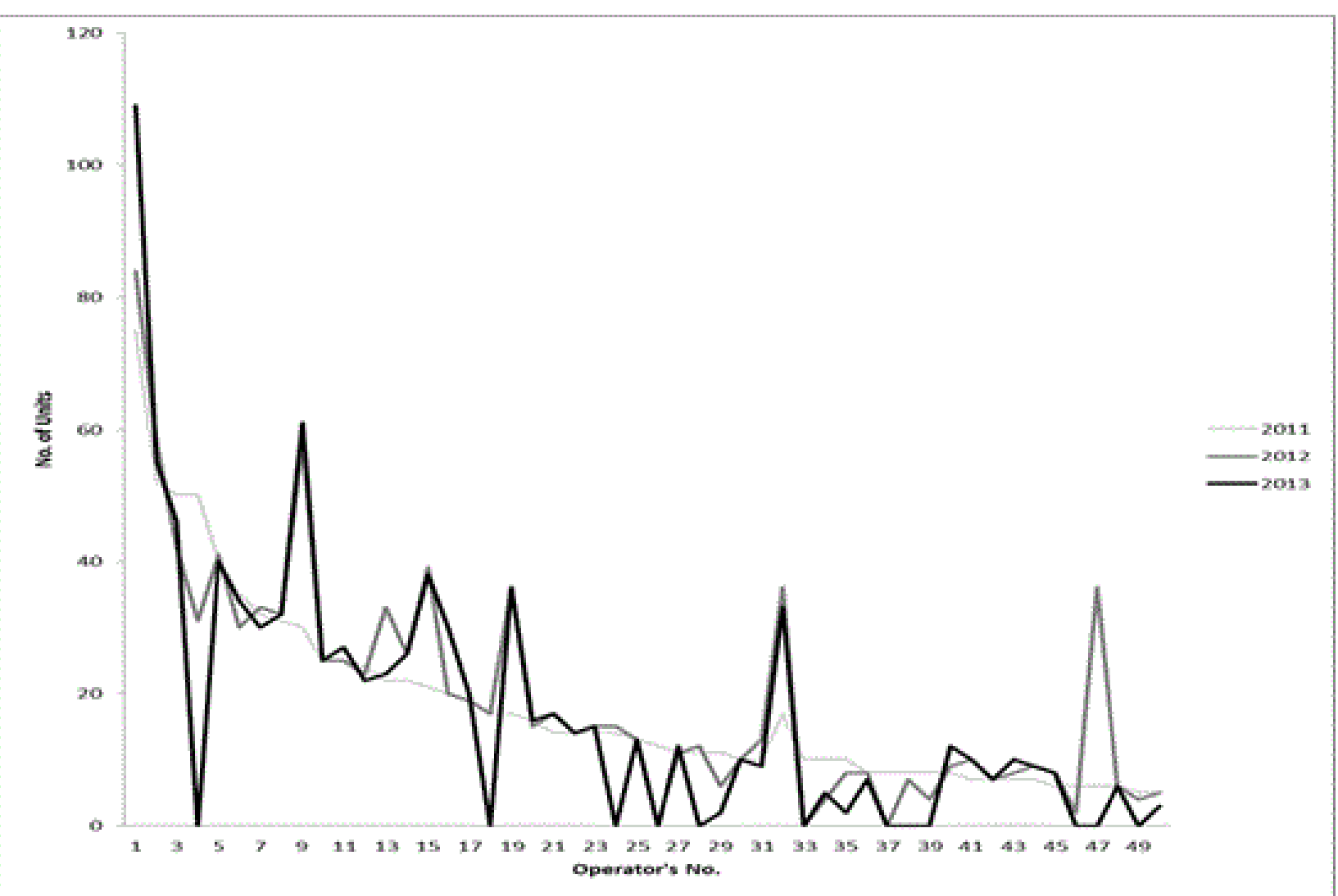

Figure 2: Trends of number of Pedicab units from 2011-2013.

\begin{tabular}{|l|l|l|l|l|}
\hline Operators & $\mathbf{2 0 1 1}$ & $\mathbf{2 0 1 2}$ & $\mathbf{2 0 1 3}$ & Average \\
\hline A & 75 & 84 & 104 & 87.67 \\
\hline B & 52 & 58 & 55 & 55 \\
\hline C & 50 & 42 & 46 & 46 \\
\hline D & 50 & 31 & NR & 40.5 \\
\hline E & 40 & 41 & 40 & 40.33 \\
\hline F & 35 & 30 & 34 & 33 \\
\hline G & 32 & 33 & 30 & 31.67 \\
\hline H & 31 & 32 & 32 & 31.67 \\
\hline I & 30 & 58 & NR & 44 \\
\hline J & 25 & 25 & 25 & 25 \\
\hline Note: NR - Not Registered & & & & \\
\hline
\end{tabular}

Table 1: Letters A-J are letter symbols for the ten Pedicab operators.

It is shown that even though there was a decline in the number of units by the year 2013, there were also operators that acquire a greater number of units after a year or so. Using One-way ANOVA, F0.207 <
Fcrit3.057, accepts that there are no significant differences in the number of Pedicab units from 2011, 2012 and 2013, 
Citation: Irene EA, Laurilla FT, Bajado JC (2015) Non-Motorized Public Transport and Tourism - The Case of Pedicab Drivers of Catbalogan,

Page 4 of 7

\section{Profile of Pedicab Drivers of Catbalogan City}

Findings of the study disclosed that most of the pedicab drivers in Catbalogan live in the rural areas of Catbalogan while others were from the city proper and nearby towns of Catbalogan. Their ages range from 18-65 years old, predominantly male, married and have three to four dependents. Most of them are elementary levels only but surprisingly, about $23 \%$ are college level and $21 \%$ have finished college degrees. In the interview with them, these Pedicab drivers finished two to four-year degree courses but they could not find a permanent job. Some of them quit and they have to resort to pedicab driving to finance their family daily expenses. Majority spent five to eight hours of driving a day, usually starting off at six AM, taking breaks during breakfast at nine AM, lunch time and nap until two PM, and resumes pedicab driving until six to seven o'clock in the evening. In terms of years of pedicab driving, most of them have spent more than five years in pedicab driving, followed by one to two years, while most of them have just started in one to two years ago. The mean of their daily net income is about Php150.00 (\$3.5) which is mostly derived from pedicab work. This daily income is not sufficient for a family of four. Millennium Development Goal benchmark is set at $\$ 2$ per day per person (Table 2).

\begin{tabular}{|c|c|c|}
\hline Demographics & Frequency & $\%$ \\
\hline \multicolumn{3}{|l|}{ Address } \\
\hline Rural & 136 & 67.00 \\
\hline City proper & 62 & 30.54 \\
\hline Outside Catbalogan & 5 & 2.46 \\
\hline \multicolumn{3}{|l|}{ Age } \\
\hline Below 15 years old & 0 & 0.00 \\
\hline $16-20$ years old & 3 & 1.24 \\
\hline $21-30$ years old & 84 & 34.71 \\
\hline $31-40$ years old & 79 & 32.64 \\
\hline $41-50$ years old & 49 & 20.25 \\
\hline More than 50 years old & 27 & 11.16 \\
\hline \multicolumn{3}{|l|}{ Marital Status } \\
\hline Single & 30 & 13.82 \\
\hline Married & 176 & 81.11 \\
\hline Widow/widower & 9 & 4.15 \\
\hline Separated & 2 & 0.92 \\
\hline \multicolumn{3}{|l|}{ Educational Attainment } \\
\hline No schooling & 1 & 0.45 \\
\hline Elementary Level & 31 & 13.90 \\
\hline Elementary Graduate & 47 & 21.08 \\
\hline High school level & 26 & 11.66 \\
\hline High school graduate & 19 & 8.52 \\
\hline College level & 51 & 22.87 \\
\hline
\end{tabular}

\begin{tabular}{|c|c|c|}
\hline College graduate & 48 & 21.52 \\
\hline \multicolumn{3}{|l|}{ Number of dependents } \\
\hline No dependent & 7 & 5.83 \\
\hline $1-2$ dependents & 35 & 29.17 \\
\hline $3-4$ dependents & 50 & 41.67 \\
\hline $5-6$ dependents & 18 & 15.00 \\
\hline $7-9$ dependents & 10 & 8.33 \\
\hline 10 or more dependents & 0 & 0.00 \\
\hline \multicolumn{3}{|c|}{ Hours Spent in Pedicab driving per day } \\
\hline $1-2$ hours & 2 & 0.91 \\
\hline 3-4 hours & 15 & 6.82 \\
\hline $5-8$ hours & 142 & 64.55 \\
\hline $9-10$ hours & 48 & 21.82 \\
\hline More than 10 hours & 13 & 5.91 \\
\hline \multicolumn{3}{|l|}{ Daily Income } \\
\hline Less than 100 & 8 & 3.85 \\
\hline $101-200$ & 86 & 41.35 \\
\hline $201-300$ & 76 & 36.54 \\
\hline $301-400$ & 31 & 14.90 \\
\hline $401-500$ & 2 & 0.96 \\
\hline More than 500 & 5 & 2.40 \\
\hline \multicolumn{3}{|l|}{ Years of pedicab driving } \\
\hline Less than one year & 60 & 27.52 \\
\hline $1-2$ years & 78 & 35.78 \\
\hline $3-4$ years & 40 & 18.35 \\
\hline $5-10$ years & 15 & 6.88 \\
\hline More than 10 years & 25 & 11.47 \\
\hline
\end{tabular}

Table 2: Profile of Pedicab driver - respondents.

It can be averred also from the data that only few are young drivers and majority are in their early adulthood which is at their early marriage stage. This observation runs congruent with the literature that those married males tend to resort to pedicab driving as their fastest means to earn income to feed their families. They cannot wait for a good job for they need to earn right away for their families. This kind of job ensures only food on their table for a day and they have to work again for tomorrow.

The phrase "desperate times calls for desperate measures" is evident among respondents who acquired college degrees and yet into pedicab driving. Because there are no available jobs around, most of them toil pedicab work rather than be an inept member of the society.

Quotes from Jason (not his real name), 21, with a wife and two kids: 
Page 5 of 7

"I have no choice. I have to work in order to feed my family. Pedicab driving is the easiest job available".

Quotes from Emar (not his real name), 24, single, college graduate and living with a family of five. His parents do not have permanent jobs:

"I did not get a permanent job. Pedicab driving is more convenient for me because you have no Boss (employer) who will tell you what to do. I say when I want to work or not".

\section{Problems, Needs and Ailments of Pedicab drivers}

Majority of them had acquired ailments due to their strenuous kind of work. Although others opined that those ailments could be hereditary, yet they are one in agreement that if they could find other stable job, they are going to leave Pedicab driving. Generally, they claimed that they are in good health; otherwise, they encounter slight ailments such as coughs and colds. Others stated that they just drink one bottle of alcoholic beverages to relieve muscle cramps and minor illnesses such as fever and colds (Table 3 ).

\begin{tabular}{|c|c|c|}
\hline Ailments, Problems and Training Needs & Frequency & $\%$ \\
\hline \multicolumn{3}{|c|}{ Ailments } \\
\hline Coughs and Colds & 100 & 46.08 \\
\hline EENT & 67 & 30.88 \\
\hline Arthritis and Rheumatism & 106 & 48.85 \\
\hline Kidney & 9 & 4.15 \\
\hline High blood pressure & 6 & 2.76 \\
\hline Diabetes & 0 & 0.00 \\
\hline Others & 40 & 18.43 \\
\hline \multicolumn{3}{|c|}{ Problems encountered } \\
\hline Work-related & 77 & 35.48 \\
\hline Family problems & 54 & 24.88 \\
\hline Schooling and living condition & 59 & 18.43 \\
\hline \multicolumn{3}{|c|}{ Training Needs } \\
\hline None & 27 & 12.44 \\
\hline Traffic Laws & 138 & 63.59 \\
\hline Pedicab Driving related & 88 & 40.55 \\
\hline Tourism related & 130 & 59.91 \\
\hline
\end{tabular}

Table 3: Ailments, Problems and Training needs of Pedicab drivers.

Most of the job-related problems they encountered were the increasing competitors in the job, the small fares, and the commotion among them as a result of the competition of getting a customer. They have indicated awareness of traffic rules because most of them have attended a seminar as it is required for registration, still, however, they opined it would be beneficial if all pedicab drivers would follow traffic rules and regulations because not all are following it. They would usually mock their fellow drivers when they are caught by traffic enforcers. They clamor to be given government aids such as Phil health and free insurance. Training needs are on traffic laws, pedicab driving and tourism related so that they can boost their daily income.

Most of the job-related problems they encountered were the increasing competitors in the job, the smaller fare, and the commotion among them as a result of competition of getting a customer. They have indicated awareness of traffic rules because most of them have attended a seminar as it is required for registration, still, however, they opined it would be beneficial if all pedicab drivers would follow traffic rules and regulations because not all are following it. They would usually mock their fellow drivers when they are caught by traffic enforcers. They clamor to be given government aids such as Phil health and free insurance. Training needs are on traffic laws, pedicab driving and tourism related so that they can boost their daily income.

\section{Recreation, Benefits and Aspirations of Pedicab drivers}

They spend their free time watching television and most of them aspire to own a house, have their own pedicab and be able to send their children to college. On the other hand, pedicab operators do not have a fixed salary and regular drivers for their units. Thus, pedicab drivers do not receive bonuses and other incentives required by law from their operator-employers. There are operators who give gifts in a form of cash or grocery items during Christmas but majorities do not give any benefits at all. Those who have social security benefits acquire it through a self-employed status. Although majority do not enjoy cash incentive from their employers, but they are entitled for a seventh-day bonus which is part of their unit rental agreement. Seventh-day bonus 
Citation: Irene EA, Laurilla FT, Bajado JC (2015) Non-Motorized Public Transport and Tourism - The Case of Pedicab Drivers of Catbalogan,

is an incentive to be free for a daily remittance of about Php70.00

(\$1.5) after the driver has rendered six straight days of driving which is similar to a free coupon on the 7th day (Table 4).

\begin{tabular}{|c|c|c|}
\hline Pedicab and Tourism & Frequency & $\%$ \\
\hline \multicolumn{3}{|l|}{ Pedicab drivers will boost tourism } \\
\hline Yes & 171 & 81.82 \\
\hline No & 17 & 8.13 \\
\hline Not sure & 21 & 10.05 \\
\hline \multicolumn{3}{|l|}{ Perceived Factors that boost tourism in Catbalogan } \\
\hline Plenty of tourist spots & 105 & 48.39 \\
\hline Cheap fares and prices & 110 & 50.69 \\
\hline Hospitable people & 102 & 47.00 \\
\hline Cheap hotels & 77 & 35.48 \\
\hline Availability of airport & 72 & 33.18 \\
\hline \multicolumn{3}{|l|}{ Means to help Pedicab for Tourists } \\
\hline Restructure Pedicab for tourists & 82 & 37.79 \\
\hline Training/seminar on Tourism for drivers & 97 & 44.70 \\
\hline Training seminar on communicating with foreigners & 74 & 34.10 \\
\hline Other help & 98 & 45.16 \\
\hline
\end{tabular}

Table 4: Perceived role of tourism to boost Pedicab income.

\section{Complaints and Violations committed by Pedicab drivers}

Commuters perceived the important role of Pedicab. Cheaper fares, readily available and airy, quiet and environment-friendly ride are some of the reasons they patronize pedicab than a motor cab. But still there are complaints filed in the office of the City Traffic Management Board as seen in the Figure 3.

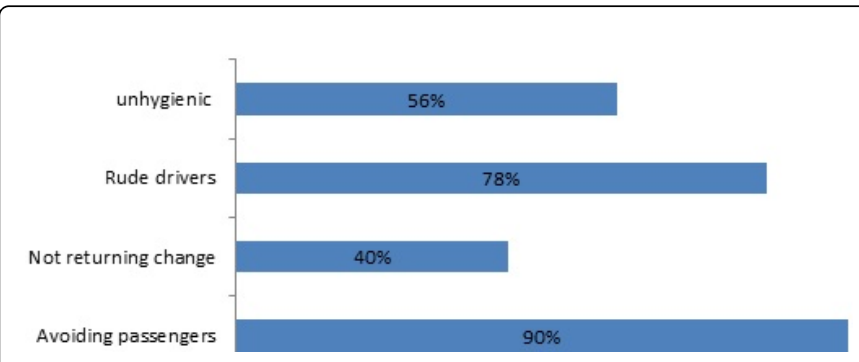

Figure 3: Complaints to Pedicab drivers.

Most complaints filed in the office of Traffic Management group of the city hall are on avoiding passengers, followed by rude and sarcastic drivers. There are also passengers complaining of the unhygienic and irritating body odors of the drivers. There were even suggestions to require them to wear a prescribed uniform. These and other solutions are still being deliberated by the council.
Violations committed by the pedicab drivers range from no registration to entry to one-way zone, no lamp at night and no posted registration stickers in their units, overloading etc. The majority of the pedicab drivers in Catbalogan have committed an offense such as riding a tricycle without a registration or expired registration pegged as the highest followed by not having a lamp at night. Others are just petty violations such as not posting a registration sticker in their unit or entering a one-way zone (Figure 4).

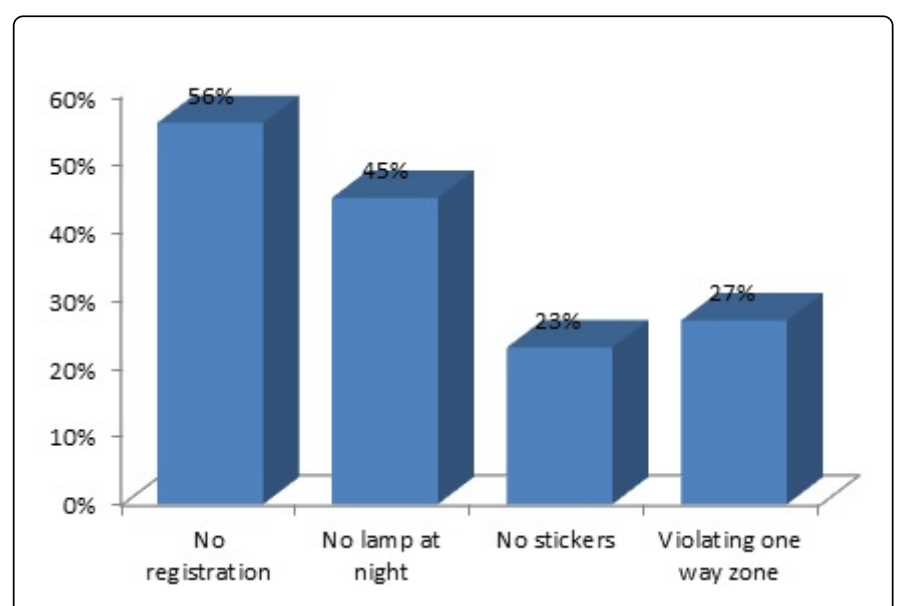

Figure 4: Violations committed by Pedicab drivers. 


\section{Tourism to Increase the Income of Pedicab drivers}

If Pedicab operation is aligned to tourism, then more tourists will come in and more profits for these drivers. Tourism can elevate the income of the poor in terms of the direct exchange of services and goods in the micro-economy [10]. In the case of the semi-skilled and unskilled rural people in Luang Prabang province, there is no denying that they earn from tourist expenditures but it is still unsure where the greatest opportunities to increase their earnings are [7]. As in the case of the Pedicab drivers in Catbalogan, most of them view tourism as a means to increase their income and half of them believe that maintaining cheap fares for tourists is one of the factors that would boost the tourism industry but they are not sure how it will profit them in the long term. They requested for financial aids to restructure their Pedicab so that it will be attractive and tourist-friendly and hence they will receive more tips. Further, majority of the respondents are willing to undergo training and seminars so they can function as tourist aides and would be able to communicate with foreigners (Table 4).

The poor and the marginalized sectors may profit from the tourism through the myriad opportunities for selling and transporting guests to and fro their destination. However the cost vis-à-vis the benefits should be considered. Tourism usually latch onto an existing tourism product or transit market and opportunities for the poor to migrate to tourism areas are affected by many factors including bureaucracy, transport, and social networks [11].

Unlike in the operation of Pedicab in other big cities in the world, Pedicab units are regulated. Say for instance in New York,

New registration is allowed if the number falls below 840 and no operators are allowed to register more than 30 units (http:// www.nyc.gov/html/dca/html/licenses/130.shtml). In this way, there is distribution of resources and can avoid disorganization and congestion of Pedicab operations [8].

\section{Conclusion and Recommendations}

Pedicab driving is the easiest source of income in Catbalogan City. Even college graduate have resorted to Pedicab driving just to ensure that they can meet their families basic needs. In order to boost the income of these drivers, developing Catbalogan tourism is seen as a means that tourists will flock to Catbalogan but there are factors and challenges that need to be addressed first to make way for tourism just as what other communities are facing [11]. One challenge is restructuring Pedicab that will attract tourists and another is to conduct training and seminars for Pedicab drivers that they can serve as functional tourist guides to them.

Pedicab drivers are dependent on Pedicab driving, hence, an institutionalized policy must be in place to support them and regulate their operations because when more tourists come, eventually there will be more Pedicab drivers and chaos will result if not properly planned [12]. Additionally, apart from emphasis on environmentally conscious planning and the needs of the urban poor (Guillen) [6] a study is yet to be ventured putting emphasis on its relationship to the tourism industry,as transportation services and facilities are integral part of tourism $[9,12]$. Since Pedicab operation is not covered by any national policy in the country [6] comprehensive local ordinances are inattentive to the regulating and revenue earning mechanisms, base fare, insurance coverage, age requirement in order to drive a pedicab unit and the provision of facilities like terminals, as in the case of Catbalogan. Hence, institutional studies $[13,14]$ suggested design for extension program that will address the needs of pedicab drivers in terms of values formation, educational and capability programs, health condition awareness, better work relations with co-worker, and value their work in order to become more contributing members of the society.

Pedicab drivers are an important sector of the working force in the community, but it has to be regulated and controlled. Thus, there is a need to review the policy in terms of the provision of the number of registration of Pedicab units. GOs and NGOs can assist this industry through providing technical and resource assistance to them to transform them to become tourism workers.

\section{References}

1. Sowman R (1993) Tourism and local government. Issues Paper-Ministry of Tourism. New Zealand 3: 7.

2. Connell J, Page SJ, Bentley T (2009) Towards sustainable tourism planning in New Zealand: Monitoring local government planning under the Resource Management Act. Tourism Management 30: 867-877.

3. Cora UN, Wong, Sarajevo, Bosnia, Herzegovina, et al. (2013) Cultural Tourism as Salvation for Petty Capitalists: the Pedicab Drivers of the Las Vegas of the East International Critical Tourism Studies. Conference V Tourism Critical Practice: Activating Dreams into Action.

4. Rebling BW (2011) Rise of the Pedicab: Municipal Regulation of an Emerging Industry. The Ariz L Rev 53: 255.

5. Conway A, Khallouki D (2014) Pedi cabs for Urban Transportation in US Cities. Transportation Research Record: Journal of the Transportation Research Board 2416: 19-26.

6. Guillen M (2000) A Study of Non-Motorized Public Transportation in Urban and Urbanizing Areas: The Case of Pedicab Operations in the City of Manila and in the Municipality of Los Baños, Laguna M.A. Urban and Regional Planning (Transportation Planning) School of Urban and Regional Planning. University of the Philippines Diliman.

7. Ashley C (2006) Participation by the poor in Luang Prabang tourism economy: Current earnings and opportunities for expansion. Overseas development institute (ODI).

8. Gu H, Ryan C (2008) Place attachment identity and community impacts of tourism-the case of a Beijing hutong. Tourism Management 29: 637-647.

9. Dahles H (2002) Tourism, small enterprises and community development. Tourism and sustainable community development.1: 154.

10. Mitchell J, Ashley C (2010) Tourism and poverty reduction: Pathways to prosperity. Earthscan.

11. Ashley C, Boyd C, Goodwin H (2000) Pro-poor tourism: putting poverty at the heart of the tourism agenda.

12. Huimin G, Ryan C (2012) Tourism destination evolution: A comparative study of Shi Cha Hai Beijing Hutong businesses and residents attitudes. Journal of Sustainable Tourism 20: 23-40.

13. Charles R, Goeldner C, Ritchie B (1995) Tourism: Principles Practices and Philosophies. (7thedn) John Wiley \& Sons. Inc New York.

14. Estrella P, Magno E (2011) Status of Pedicab Drivers in Dinalupihan: Basis for Extension Program. BPSU Research Journal. Bataan Polytechnic State University 3: 29-50. 